\title{
Short communication: Lying behavior of lactating dairy cows is influenced by lameness especially around feeding time
}

\author{
C. Yunta, ${ }^{*}$ I. Guasch, $†$ and A. Bach* $\ddagger^{1}$ \\ *Department of Ruminant Production, Institut de Recerca i Tecnologia Agroalimentàries (IRTA), 08140 Caldes de Montbui, Spain \\ †La Pirenaica, La Seu d'Urgell, Spain \\ łInstitució Catalana de Recerca i Estudis Avançats (ICREA), 08010 Barcelona, Spain
}

\section{ABSTRACT}

Lameness is considered one of the most common welfare and productive problems in dairy cattle. The objective of this study was to evaluate differences in lying behavior between moderately lame and nonlame lactating cows under commercial conditions. Data were collected from 10 free-stall commercial herds, which were feeding on exactly the same ration once daily. All lactating cows were scored for lameness according to a 1 to 5 locomotion scoring system. Only cows with a lameness score between 1 and 4 were considered in the study. In each herd, between 10 and 15 lame cows (scored as 3 or 4 ) were chosen, and for each lame cow, a nonlame cow (scored as 1) within the same parity and similar days in milk was also selected. Pendant data loggers were then placed on the right hind leg of each cow for $10 \mathrm{~d}$ to record lying behavior at 1-min intervals. In addition, the time of feed delivery was recorded in each herd on a daily basis. Total daily lying time, daily number of lying bouts, lying bout duration, laterality (side of recumbence), and lying behavior around feed delivery time were evaluated using a mixed-effects model that accounted for the fixed effects of lameness, days in milk, parity, and the interaction between parity and lameness, plus the random effects of herd. Total daily lying time $(721 \pm 24.2 \mathrm{~min} / \mathrm{d})$ tended to increase with days in milk, but it was not affected by lameness or parity. Likewise, no differences were found in the number of lying bouts $(9.6 \pm 0.49 / \mathrm{d})$ or laterality (47 $\pm 2.6 \%$ of time lying on the right side). However, the mean bout duration was longer in lame $(89.3 \pm 3.89$ min) compared with nonlame $(80.7 \pm 3.90 \mathrm{~min})$ cows. It is interesting that lame cows stood up $13 \mathrm{~min}$ later than nonlame cows relative to the time when the ration was delivered. In addition, lame cows lay down $19 \mathrm{~min}$ earlier than nonlame ones after the feed was delivered, which implies that nonlame cows spent more time

Received April 29, 2012.

Accepted July 19, 2012.

${ }^{1}$ Corresponding author: alex.bach@irta.cat standing, and probably eating, than did lame cows. It was concluded that lame cows have longer lying bouts than nonlame animals, and that lying behavior around feed delivery time may be an effective proxy to identify moderately lame cows.

Key words: behavior, feeding, lameness, lying

\section{Short Communication}

Lameness is a widely recognized welfare problem for dairy cows that has a high prevalence, with reports in the United States and United Kingdom ranging between 25 and 37\% (Espejo et al., 2006; Barker et al., 2010) In addition, lameness is thought to be an important cause of economic losses because of treatment costs (Kossaibati and Esslemont, 1997), milk production losses (Bach et al., 2007; Green et al., 2010), impaired fertility (Whay et al., 2003), and premature culling (Bicalho et al., 2007). Early detection of lame animals may allow for a fast recovery, improved welfare, and a reduction in treatment costs and increased efficacy. However, early identification of lameness in dairy cows is difficult and relies on subjective identification by farm personnel. Thus, it is necessary to develop and improve low-timeconsuming and effective methods that allow early detection of the disorder. Automatic data records of behavioral changes, such as lying time per day, may be a good alternative to achieve this goal (von Keyserlingk et al., 2009). Pain and discomfort caused by lameness leads to changes in resting, walking, and feeding times (González et al., 2008; Ito et al., 2010). Some researchers have already attempted to identify these behavioral changes through measures of weight distribution (Pastell et al., 2010), number of visits to automated milking systems (Borderas et al., 2008), or vertical ground reaction force while the cows walk (Rajkondawar et al., 2006). Feeding behavior is another plausible indicator of health problems in dairy cattle. For example, lame cows show a reduced feeding time and number of visits to the feeders (González et al., 2008), and they prefer to eat in the feed bunk spaces closest to the exit of the milking parlor (Bach et al., 2007). Severely lame 
cows are easily detected by producers; however, a need, and an opportunity, exists to detect moderately lame cows by using alternative technologies. The objective of this study was to evaluate differences in lying behavior (such as daily lying time, lying bouts, and posture around feeding) between moderately lame and nonlame lactating cows under commercial conditions to assess whether changes in behavior could be used as a proxy for lameness detection.

Ten free-stall commercial herds, which were feeding exactly the same ration once daily, were enrolled in this study. The average milk production of the herds was $35.2 \pm 6.20 \mathrm{~kg} / \mathrm{d}$, and the average herd size was $129 \pm$ 57.8 lactating cows (mean \pm SD). All farms used straw as bedding material for the stalls and had concrete alleys, except one that had rubber flooring in the feed alley. All farms milked cows twice daily and fed once daily. The TMR was centrally manufactured (La Pirenaica, La Seu d'Urgell, Spain) using the same ingredients (both concentrate and forages) and was distributed by truck to each herd on a daily basis (for details see Bach et al., 2008). The first day of the study, during the morning milking, all lactating cows within each herd were scored for lameness as they exited the parlor by using the locomotion score described by Sprecher et al. (1997). This method uses a 5-point scale, with 1 being assigned to sound cows and 5 being assigned to severely lame animals. Because the objective was to evaluate whether differences in lying behavior could be identified between sound and moderately lame cows, only cows with a lameness score of 1,3 , or 4 were included in the current study. All cows were scored by the same previously trained observer. Cows with a locomotion score of 1 were considered sound, and those with a locomotion score of 3 or 4 were considered moderately lame. Cows with a score of 5 were discarded because these types of animals are easily spotted by producers, and cows with scores of 3 and 4 were grouped into a single class (moderately lame) because of the difficulty, on some occasions, of deciding between the 2 scores for a given cow. In fact, the intraobserver reliability increased from 0.82 to 0.97 when these 2 categories were combined. In each herd, between 10 and 15 lame cows were selected (depending on cow availability). Within each herd, all the selected lame cows were paired with a nonlame cow with an equal parity number and similar DIM. The average daily milk yield of the selected sound cows was $30.8 \pm 8.70 \mathrm{~kg} / \mathrm{d}$, with $3.94 \pm 0.61 \%$ fat and $3.71 \pm 0.35 \%$ protein; the average parity number was $2.38 \pm 1.43$; and the average DIM was $186 \pm 102.2 \mathrm{~d}$ (mean $\pm \mathrm{SD})$. For the selected moderately lame cows, milk yield was $29.2 \pm 8.75 \mathrm{~kg} / \mathrm{d}$, milk fat content was $4.07 \pm 0.76 \%$, milk protein content was $3.67 \pm 0.41 \%$, average parity was $2.45 \pm 1.46$, and average DIM was $190 \pm 115.9$ d (mean \pm SD).

For 10 consecutive days, pendant data loggers (HOBO Pendant G Acceleration Data Loggers, Onset Computer Corp., Pocasset, MA) were placed on the right hind leg of each cow by using cohesive bandages (Eurimexflex, Divasa Farmavic, Barcelona, Spain) as described by Ledgerwood et al. (2010). Data loggers were programmed to record measurements at 1-min intervals. During the $10 \mathrm{~d}$ of the study, the time of feed delivery was also recorded in each herd on a daily basis.

Data from the data loggers were recovered using HOBOwarePro software (Onset Computer Corporation, Bourne, MA) and exported into a text file, which was processed according to the method of Ledgerwood et al. (2010). Briefly, a Python script was used to determine when the animals were standing up by using data from the y-axis, and if the animals were lying, the side of recumbency was determined using data from the z-axis. The same script was used to calculate daily lying time, number of lying bouts per day, and laterality (side of recumbency). The average bout duration was calculated by dividing daily lying time by the number of bouts per day. Additionally, for each focal cow, behavior around feeding was evaluated by calculating the time that cows stood up and remained standing and the time when cows lay down again with respect to feed delivery time. Total daily lying time, daily number of lying bouts, lying bout duration, laterality, and lying behavior around feed delivery were averaged for the entire $10 \mathrm{~d}$ within each cow and herd. All data were normally distributed. Summarized data were evaluated using a mixed-effects model that accounted for the fixed effects of lameness score, DIM, and parity, plus the random effects of herd, using SAS software (v. 9.2, SAS Institute Inc., Cary, NC). The interactions between parity and lameness, and parity and DIM were initially part of the model, but were later removed because they were not significant.

No differences $(P=0.20)$ in milk yield $(30.1 \pm 0.68$ $\mathrm{kg} / \mathrm{d}$ ) were observed between moderately lame and sound cows. Similarly, no differences $(P>0.19)$ in milk fat $(4.01 \pm 0.08 \%)$ or milk protein $(3.69 \pm 0.03 \%)$ were observed between lame and sound cows. Overall, average lying time was $721 \pm 24.2 \mathrm{~min} / \mathrm{d}$ and tended $(P=$ $0.07)$ to increase with DIM. This overall lying time is in accordance with previous studies (Cook et al., 2005; Ledgerwood et al., 2010; Blackie et al., 2011). Contrary to our initial expectations, moderate lameness did not influence $(P=0.83)$ lying time, with sound cows lying an average of $714 \pm 24.2 \mathrm{~min} / \mathrm{d}$ and moderately lame cows lying an average of $728 \pm 24.2 \mathrm{~min} / \mathrm{d}$. A potential reason for the lack of association between ly- 
ing time and lameness in the current study could be that severely lame cows (lameness score $=5$ ) were not considered in the study. Nevertheless, results on lying time and lameness are contradictory in the literature. Most studies report an increase (Galindo and Broom, 2002; Blackie et al., 2011), others report a decrease (Cook et al., 2008), and others, as the current study, report no differences (Ito et al., 2010) in lying time for lame cows. Therefore, lying time per se does not seem a potentially useful indicator for detecting moderate lameness in dairy herds.

The average number of lying bouts $(9.6 \pm 0.49$ bouts/d) was not affected $(P=0.18)$ by lameness or parity, with sound cows lying an average of $9.8 \pm 0.49$ times a day and moderately lame cows lying an average of $9.4 \pm 0.49$ times a day. However, the average bout duration was longer $(P<0.05)$ for lame $(89.3 \pm$ $3.89 \mathrm{~min} /$ bout $)$ than for nonlame cows $(80.7 \pm 3.90$ $\mathrm{min} /$ bout). These results are in concordance with other studies conducted in free-stalls barns (Cook et al., 2005; Ito et al., 2010); thus, bout duration could be a potentially useful proxy for lameness detection. Cows had no preferences for lying down on the right or on the left side independently of lameness, and overall, cows lay down on the right side $47 \pm 2.6 \%$ of the occasions. This observation is in agreement with previous reports (Phillips et al., 2003; Tucker et al., 2009).

It is interesting that around feeding time, the standing behavior of lame cows was different from that of sound cows. Lame cows stood up $(-21.6 \pm 5.38 \mathrm{~min})$ 13 min later $(P<0.05)$ than did nonlame cows $(-34.4$ $\pm 5.42 \mathrm{~min}$ ) relative to the time when the ration was delivered, and they lay down 19 min earlier (23.3 \pm 9.23 vs. $41.9 \pm 9.27 \mathrm{~min}$, respectively; $P<0.05$ ). Thus, nonlame cows would have had potentially longer feeding times when fresh feed was delivered (the actual time spent eating was not recorded in the current study) than moderately lame cows. To our knowledge, this is the first study to evaluate changes in feed bunk attendance in lame cows across different herds. Bach et al. (2007) reported that the number of visits to the feed bunk was not affected by the locomotion score of cows milked in a automatic milking system; however, lame cows preferred feed bunk spaces that were the nearest to the milking exit. It could be speculated, based on the fact that lame cows stood up (presumably to reach the fed bunk) later than sound cows and spent less time standing after the feed was delivered, either that lame cows consumed the same amount of feed as sound cows but at faster rate (potentially compromising rumen health), as described by González et al. (2008), or that lame cows consumed less feed than sound cows at an unaltered eating rate. In any case, results from the current study indicate that paying attention to those cows that remain lying down around the time when fresh feed is delivered and those that lie down early after feed is offered seems an effective way to detect lame cows.

In summary, the current study allowed the potential effect of nutrition to be removed when evaluating potential changes in lying behavior across different herds (because all herds were fed the same ration). The lying bout duration of cows kept under commercial conditions was influenced by lameness, but at this point, daily lying time and laterality cannot be considered good proxies for early moderate lameness detection. The most significant aspect of the results presented herein is the change in lying behavior around the moment of the day when fresh feed is delivered. In this regard, the results show promise for using lying behavior around feed delivery to identify lame cows.

\section{REFERENCES}

Bach, A., M. Dinarés, M. Devant, and X. Carré. 2007. Associations between lameness and production, feeding and milking attendance of Holstein cows milked with an automatic milking system. J. Dairy Res. 74:40-46.

Bach, A., N. Valls, A. Solans, and T. Torrent. 2008. Associations between nondietary factors and dairy herd performance. J. Dairy Sci. 91:3259-3267.

Barker, Z. E., K. A. Leach, H. R. Whay, N. L. Bell, and D. C. J. Main. 2010. Assessment of lameness prevalence and associated risk factors in dairy herds in England and Wales. J. Dairy Sci. 93:932-941.

Bicalho, R. C., F. Vokey, H. N. Erb, and C. L. Guard. 2007. Visual locomotion scoring in the first seventy days in milk: Impact on pregnancy and survival. J. Dairy Sci. 90:4586-4591.

Blackie, N., J. Amory, E. Bleach, and J. Scaife. 2011. The effect of lameness on lying behaviour of zero grazed Holstein dairy cattle. Appl. Anim. Behav. Sci. 134:85-91.

Borderas, T. F., A. Fournier, J. Rushen, and A. M. B. de Passillé. 2008. Effect of lameness on dairy cows' visits to automatic milking systems. Can. J. Anim. Sci. 88:1-8.

Cook, N. B., T. B. Bennett, and K. V. Nordlund. 2005. Monitoring indices of cow comfort in free-stall-housed dairy herds. J. Dairy Sci. 88:3876-3885.

Cook, N. B., M. J. Marin, R. L. Mentink, T. B. Bennett, and M. J. Schaefer. 2008. Comfort zone-design free stalls: Do they influence the stall use behavior of lame cows? J. Dairy Sci. 91:4673-4678.

Espejo, L. A., M. I. Endres, and J. A. Salfer. 2006. Prevalence of lameness in high-producing Holstein cows housed in freestall barns in Minnesota. J. Dairy Sci. 89:3052-3058.

Galindo, F., and D. M. Broom. 2002. The effects of lameness on social and individual behavior of dairy cows. J. Appl. Anim. Welf. Sci. 5:193-201.

González, L. A., B. J. Tolkamp, M. P. Coffey, A. Ferret, and I. Kyriazakis. 2008. Changes in feeding behavior as possible indicators for the automatic monitoring of health disorders in dairy cows. J. Dairy Sci. 91:1017-1028.

Green, L. E., J. Borkert, G. Monti, and N. Tadich. 2010. Associations between lesion-specific lameness and the milk yield of 1,635 dairy cows from seven herds in the Xth region of Chile and implications for management of lame dairy cows worldwide. Anim. Welf. 19:419-427.

Ito, K., M. A. G. von Keyserlingk, S. J. LeBlanc, and D. M. Weary. 2010. Lying behavior as an indicator of lameness in dairy cows. J. Dairy Sci. 93:3553-3560.

Kossaibati, M. A., and R. J. Esslemont. 1997. The costs of production diseases in dairy herds in England. Vet. J. 154:41-51. 
Ledgerwood, D. N., C. Winckler, and C. B. Tucker. 2010. Evaluation of data loggers, sampling intervals, and editing techniques for measuring the lying behavior of dairy cattle. J. Dairy Sci. 93:5129-5139.

Pastell, M., L. Hänninen, A. M. de Passillé, and J. Rushen. 2010. Measures of weight distribution of dairy cows to detect lameness and the presence of hoof lesions. J. Dairy Sci. 93:954-960.

Phillips, C. J. C., S. Llewellyn, and A. Claudia. 2003. Laterality on bovine behavior in an extensive partially suckled herd and an intensive dairy herd. J. Dairy Sci. 86:3167-3173.

Rajkondawar, P. G., M. Liu, R. M. Dyer, N. K. Neerchal, U. Tasch, A. M. Lefcourt, B. Erez, and M. A. Varner. 2006. Comparison of models to identify lame cows based on gait and lesion scores, and limb movement variables. J. Dairy Sci. 89:4267-4275.
Sprecher, D. J., D. E. Hostetler, and J. B. Kaneene. 1997. A lameness scoring system that uses posture and gait to predict dairy cattle reproductive performance. Theriogenology 47:1179-1187.

Tucker, C. B., N. R. Cox, D. M. Weary, and M. Spinka. 2009. Laterality of lying behaviour in dairy cattle. Appl. Anim. Behav. Sci. 120:125-131.

von Keyserlingk, M. A. G., J. Rushen, A. M. de Passillé, and D. M. Weary. 2009. Invited review: The welfare of dairy cattle - Key concepts and the role of science. J. Dairy Sci. 92:4101-4111.

Whay, H. R., D. C. J. Main, L. E. Green, and A. J. F. Webster. 2003. Assessment of the welfare of dairy cattle using animal-based measurements: Direct observations and investigation of farm records. Vet. Rec. 153:197-202. 